\title{
Effects of bromocriptine and perphenazine on prolactin and progesterone concentrations in pregnant pony mares during late gestation
}

\author{
F. A. Ireland, W. E. Loch*, K. Worthy and R. V. Anthony \\ Department of Animal Sciences, University of Missouri, Columbia, MO 65211, USA
}

\begin{abstract}
Summary. Pregnant pony mares in Group A $(n=4)$ received i.m. injections at 07:00 and $17: 00 \mathrm{~h}$ of $0.8 \mathrm{mg}$ bromocriptine $/ \mathrm{kg}$ body weight ${ }^{0.75}$ per day beginning on Day 295 of gestation and continuing until parturition. Group B $(n=4)$ was treated similarly, but perphenazine was administered orally at $0.375 \mathrm{mg} / \mathrm{kg}$ body weight twice a day beginning on Day 305 of gestation and continuing until parturition. Mares in Group C $(n=3)$ received i.m. injections of saline. Mean plasma prolactin and progesterone concentrations were greater $(P<0.05)$ for mares in Group $\mathrm{C}$ than in Groups $\mathrm{A}$ and $\mathrm{B}$ from 295 to 309 days of gestation. From 305 days of gestation, plasma prolactin and progesterone concentrations were greater $(P<0.05)$ in Group B and C than in Group A mares. Progesterone and prolactin concentrations increased over this period for Group B and Group C mares, but remained constant in Group A mares. From 10 days pre partum through foaling, mares in Group A had lower progesterone $(P<0.05)$ and prolactin $(P<0.01)$ concentrations than Group B and C mares. All mares in Group A were agalactic at foaling, while all mares in Groups $B$ and $C$ had normal milk secretion. Gestation was longer $(P<0.05)$ in Group A than in Group C mares. In Group A, 2 mares retained the placenta for $>3 \mathrm{~h}, 3$ mares had dystocia and all 4 mares had thickened, haemorrhagic placentae. There was no incidence of dystocia, thickened or retained placentae in Groups B or C. Bromocriptine appears to produce clinical signs in mares in late pregnancy similar to those in mares affected by tall fescue (Festuca arundinacea) pasture infected with the fungus Acremonium coenophialum. Perphenazine, administered orally, may be useful in treatment of mares affected by ergot alkaloids.
\end{abstract}

Keywords: bromocriptine; perphenazine; prolactin; mare

\section{Introduction}

Tall fescue (Festuca arundinacea) infected with the endophyte fungus Acremonium coenophialum has been associated with various reproductive abnormalities in pregnant mares in late gestation. The symptoms include agalactia, weak or stillborn foals, as well as placental abnormalities (Garrett, 1980; Swantner, 1986; Loch et al., 1987). Endophyte-infected tall fescue seed reduces prolactin and progesterone concentrations in pregnant mares in late gestation (Kosanke et al., 1987). Endophytic fungi contain ergot alkaloids and ergopeptides (Lyons et al., 1986) which bind dopamine receptors (Berde \& Sturmer, 1978) and inhibit release of prolactin from dispersed bovine pituitary cells in vitro (Sheeler et al., 1985). Schillo et al. (1988) indicated that endophyte-induced hypoprolactinaemia resulted from direct inhibition of prolactin release and alteration of dopaminergic neuron activity.

*Reprint requests. 
Several phenothiazine derivatives have been reported to induce a rise in blood prolactin concentrations in humans and other mammals (Ben-David et al., 1965, 1970; Musey et al., 1986). Perphenazine, a phenothiazine derivative, has been reported to have hyperprolactinaemic properties in humans (Musey et al., 1986) and can increase plasma prolactin concentrations in nonpregnant pony mares (Lock et al., 1990).

This study evaluated the potential of bromocriptine, a commercially available dopamine agonist similar in structure to the ergot alkaloids identified in toxic fescue, to reproduce fescue toxicity symptoms in pregnant pony mares. The possibility of restoration of normal hormone profiles and elimination of reproductive abnormalities, in the presence of an ergot alkaloid, by perphenazine was investigated.

\section{Materials and Methods}

Pregnant pony mares (mean body weight $256 \mathrm{~kg}$ ) were randomly assigned to one of three treatment groups on the basis of expected foaling dates. Group A $(n=4)$ received bromocriptine (Sigma Chemical Co., St. Louis, MO, USA) intramuscularly at $07: 00$ and $17: 00 \mathrm{~h}$ at $0.08 \mathrm{mg} / \mathrm{kg}$ body weight ${ }^{0.75}$ per day beginning on Day 295 of gestation and continuing until parturition; this dose was based on the data of Johnson \& Becker (1987). Group B $(n=4)$ received the same treatment as Group A with the addition of oral perphenazine (Sigma) at $0.375 \mathrm{mg} / \mathrm{kg}$ body weight twice a day at 07:00 and 17:00 h beginning on Day 305 of gestation and continuing until parturition; the dose was based on a previous experiment from this laboratory (Loch et al., 1990). Group C $(n=3)$ received an intramuscular injection of saline $(0.9 \% \mathrm{NaCl}, \mathrm{w} / \mathrm{v})$ equivalent in volume to the injections given to mares in Group $\mathrm{A}$. The dopamine receptor agonist bromocriptine (2-bromo- $\alpha$-ergocryptine), was dissolved in absolute ethyl alcohol $(5 \mathrm{mg} / \mathrm{ml})$ and extended with $0.9 \%(\mathrm{w} / \mathrm{v}) \mathrm{NaCl}$ to give a final concentration of $0.5 \mathrm{mg} / \mathrm{ml}$. Lactic acid $(85 \%)$ was used to adjust the $\mathrm{pH}$ to $3 \cdot 5$. All mares received the same diet of mixed grass hay and a concentrate mix. The mares were kept in outside paddocks throughout the experiment and exposed to ambient temperature and daylight. At parturition, placentae were collected and time of expulsion was recorded. The placentae were visually evaluated for thickness. Gestation length was recorded for all mares.

Blood collection. Blood samples were collected into heparinized tubes by jugular venepuncture at 09:50 and 17:00 $\mathrm{h}$ (immediately before drug administration), every other day from Day 295 to Day 321 of gestation and daily thereafter until parturition. All blood samples were centrifuged at $1500 \mathrm{~g}$ for $20 \mathrm{~min}$ at $5^{\circ} \mathrm{C}$. The plasma was decanted, separated into two duplicate samples and stored at $-20^{\circ} \mathrm{C}$.

Prolactin radioimmunoassay. Plasma prolactin concentrations were measured using a homologous, doubleantibody radioimmunoassay with highly purified horse prolactin as standard and antiserum raised against this standard. The prolactin preparation was purified and characterized by Li \& Chung (1983), and had a biological potency of $42 \mathrm{i} . \mathrm{u}$./mg in the pigeon crop-sac assay. The antiserum, standard and assay method were as described by Roser $e t a l$. (1984) with the following modifications to the method. Ten $\mu \mathrm{l}(\mathrm{l} \mathrm{mCi})$ of $\mathrm{Na}^{125}$ ] (Amersham Corp., Arlington Heights, IL, USA) was added to a vial containing $5 \mu \mathrm{g}$ horse prolactin $(0 \cdot 5 \mu \mathrm{g} / \mu \mathrm{l})$. The iodination was then initiated at room temperature by the addition of $20 \mu$ l of a lactoperoxidase solution (Calbiochem Corp., La Jolla, CA. USA) in $0.5 \mathrm{M}$ phosphate buffer, pH 7.5 (1.0 $\mathrm{g} / 20 \mu \mathrm{l} ; 0.1$ units $/ 20 \mu \mathrm{l})$ and $20 \mu \mathrm{H} \mathrm{H}_{2} \mathrm{O}_{2}(\mathrm{l}: 60000$ dilution of a $30 \%$ solution). The reaction was allowed to continue for $3 \mathrm{~min}$ and then $300 \mu \mathrm{l} 0.5 \mathrm{M}$ phosphate buffer was added and the mixture vortexed. The radiolabelled hormone was separated from free iodine by Sephadex G-75 $(1.0 \times 45 \mathrm{~cm})$ size-exclusion chromatography and eluted with $0.05 \mathrm{M}$ phosphate buffer, $\mathrm{pH} 7 \cdot 4$, containing $0.15 \mathrm{M}-\mathrm{NaCl}, 0.5 \%$ bovine serum albu$\min (B S A)$ and thimerosal $(0.1 \mathrm{~g} / \mathrm{l})$. Integrity and purity of the radiolabelled hormone was examined by $12.5 \%$ sodium dodecyl sulphate polyacrylamide gel electrophoresis and autoradiography. The specific activity of the ${ }^{125} \mathrm{I}$-labelled horse prolactin obtained was evaluated using trichloroacetic acid precipitation and calculated to be $40 \cdot 75 \mu \mathrm{Ci} / \mu \mathrm{g}$. All samples were analysed using tracer obtained from a single iodination.

The assay buffer was $0.01 \mathrm{~m}$ sodium phosphate, $\mathrm{pH} 7 \cdot 4$, containing $0.15 \mathrm{M}-\mathrm{NaCl}, 0.5 \% \mathrm{BSA}, 0.01 \mathrm{M}$ EDTA, and thimerosal $(0.1 \mathrm{~g} / \mathrm{l})$. To $0.1 \mathrm{ml}$ of unlabelled prolactin (sample or standard) was added $0.1 \mathrm{ml}{ }^{125} \mathrm{I}$-labelled horse prolactin and $0 \cdot 1 \mathrm{ml}$ rabbit antihorse prolactin serum (1:15000 dilution with normal rabbit serum, 1:200) (Roser $e t$ al., 1984). After incubation for $16 \mathrm{~h}$ at $4^{\circ} \mathrm{C}, 0.2 \mathrm{ml}$ goat antirabbit immunoglobulin $\mathrm{G}$ (1:60; Sigma) was added and a second incubation was carried out for $16 \mathrm{~h}$ at $4^{\circ} \mathrm{C}$. Separation of the free and precipitated radioactivity was achieved by adding $1 \mathrm{ml}$ cold distilled water and centrifuging the tubes at $1500 \mathrm{~g}$ for $30 \mathrm{~min}$. The antibody-bound, ${ }^{125} \mathrm{I}$-labelled horse prolactin in the precipitate was counted using an automatic gamma spectrometer (LKB-Wallace Model 1277; $70 \%$ efficiency). The displacement of antibody-bound, ${ }^{125}$ I-labelled horse prolactin by various concentrations of standard horse prolactin $(0 \cdot 15-20 \mathrm{ng})$ was determined and expressed as a percentage of the ratio of the specifically bound hormone to the amount of ${ }^{125}$ I-labelled horse prolactin bound to antibody, in the absence of unlabelled hormone minus the nonspecifically bound ${ }^{125} \mathrm{I}$-labelled prolactin. This technique gave a stable tracer with a total binding of $22 \cdot 66 \%$ and a nonspecific binding of $2 \cdot 0 \%$ at an initial dilution of the primary antiserum of $1: 15000$. Accuracy and precision were evaluated by the addition of equine prolactin to a pool of gelding plasma to a final 
concentration of $20 \mathrm{ng} / 100 \mu \mathrm{l}$. The spiked pool was assayed (in duplicate) at $20,40,60,80$ and $100 \mu$ doses yielding estimates of $18 \cdot 2,17 \cdot 2,22 \cdot 8,20 \cdot 2$ and $21 \cdot 2 \mathrm{ng} / 100 \mu \mathrm{l}$, respectively. A pool of mare plasma $(20 \mathrm{ng} / \mathrm{ml})$ was included in each assay $(n=6)$ at 25,50 and $100 \mu l$ doses to determine intra- and interassay coefficients of variation. The intraassay coefficients of variation were $12.75,14.18$ and $6.59 \%$ and the interassay coefficients of variation were 24.97 , 30.85 and $29.22 \%$ for the 25.50 and $100 \mu l$ doses, respectively. The intra-assay and interassay coefficients of variation for an additional plasma pool $(16 \cdot 79 \mathrm{ng} / \mathrm{ml})$ included in each assay $(n=6)$ were $10 \cdot 76 \%$ and $18 \cdot 00 \%$, respectively. The limit of detection for the prolactin assay, defined as the lowest standard value that could be discriminated from zero values at the $95 \%$ confidence level, was $1.5 \mathrm{ng} / \mathrm{ml}$.

Progesterone radioimmunoassay. Plasma progesterone concentrations were determined by radioimmunoassay techniques using a commercially available progesterone kit (Srikandakumar et al., 1986; Coat-A-Count, Diagnostic Products Corp., Los Angeles, CA, USA). The displacement of antibody-bound hormone by various concentrations of standard progesterone $(0.01-4.0 \mathrm{ng})$ was determined and expressed as a percentage of the ratio of specifically bound progesterone to the amount of ${ }^{125}$ I-labelled progesterone bound to antibody, in the absence of unlabelled hormone minus the nonspecifically bound ${ }^{125}$ I-labelled progesterone. This technique resulted in an average total binding and nonspecific binding for all assays $(n=8)$ of $42 \cdot 13 \%$ and $1 \cdot 39 \%$, respectively. The interassay and intra-assay coefficients of variation for progesterone, based on plasma pools (high and low pools) included in each assay $(n=8)$, were $5.57 \%$ and $5 \cdot 1 \%$, respectively. The limit of detection for the assay was $0.1 \mathrm{ng} / \mathrm{ml}$.

Statistical analysis. Hormone concentration data were analysed by least-squares analysis of variance using a splitplot over time (day relative to initial bromocriptine administration, day relative to initial perphenazine administration, or day relative to foaling) design (Gill \& Hafs, 1971). The whole-plot main effects of treatment and time of day, and the appropriate interactions were tested with the whole-plot error mean square. The subplot main effect of day was interacted with the whole-plot main effects and these were tested using the subplot residual mean square. For data obtained relative to the onset of bromocriptine administration, the orthogonal contrasts of Group $C$ vs. Groups A + B, and Group A vs. Group B were fitted. Orthogonal contrasts of Group A vs. Group B + C, and Group B vs. Group $C$ were fitted for data obtained relative to foaling and relative to initial perphenazine administration. The incidences of agalactia, dystocia, and retained placentae were analysed by $\chi^{2}$ analyses.

\section{Results}

\section{Hormone concentrations}

Plasma progesterone concentrations from 295 to 309 days of gestation (Fig. 1a) were not affected by time of day, but mean concentration was greater $(P<0.05)$ in Group $C$ mares than in Group $A$ and $B$ mares $(15.71 \pm 2.20$ vs. $10.63 \pm 1.91$ and $9.15 \pm 1.90 \mathrm{ng} / \mathrm{ml})$. The profiles indicated that Group $\mathrm{C}$ mares exhibited a steady increase in plasma progesterone concentrations over this period, whereas Group A and B mares did not (day-linear $\times$ treatment for Group C vs. Group A and Group B; $P<0.01)$. Group A and B mares did not differ $(P>0 \cdot 10)$ in mean plasma progesterone concentrations during this time. As with progesterone, plasma prolactin concentrations (Fig. 1b) were greater $(P<0.05)$ in control mares than in Group A and B mares $(29.04 \pm 4.12$ vs. $12.35 \pm 3.64$ and $20.82 \pm 3.63 \mathrm{ng} / \mathrm{ml}$ ) from 295 to 309 days of gestation, but were not influenced by time of day $(P>0 \cdot 10)$. The quadratic subplot regressions for day $\times$ treatment were different $(P<0.01)$ for Group C vs. Group A and B mares. Within-day fluctuation (09:50 vs. 17:00 h) in prolactin increased from Day 295 to Day 309, as demonstrated by the difference $(P<0.01)$ in the linear subplot regressions for day $\times$ time of day.

From 305 days of gestation, when mares in Group B began receiving perphenazine as well as bromocriptine, until 311 days of gestation, concentrations of progesterone (Fig. 1c) and prolactin (Fig. 1d) were greater $(P<0.05)$ in Group $C$ and B mares than in Group A mares $(21.68 \pm 3.34$ and $13.17 \pm 2.9$ vs. $9.80 \pm 2.80 \mathrm{ng}$ progesterone $/ \mathrm{ml} ; 36.01 \pm 6.44$ and $26.28 \pm 4.71$ vs. $12.68 \pm 4.81 \mathrm{ng}$ prolactin $/ \mathrm{ml}$ ). Mares receiving perphenazine and bromocriptine had lower $(P<0.05)$ concentrations of progesterone than mares in the control group. Progesterone and prolactin concentrations increased during this period for Group $\mathrm{C}$ and $\mathbf{B}$ mares, but remained constant in Group A mares (day-linear $\times$ treatment for Group A vs. Groups B and C; $P<0 \cdot 01$ ). The cubic subplot regressions of day $\times$ treatment $(P<0.05)$ for progesterone were different for Group $B$ and $\mathrm{C}$ mares, because progesterone concentrations in Group B mares were low and similar to those in 

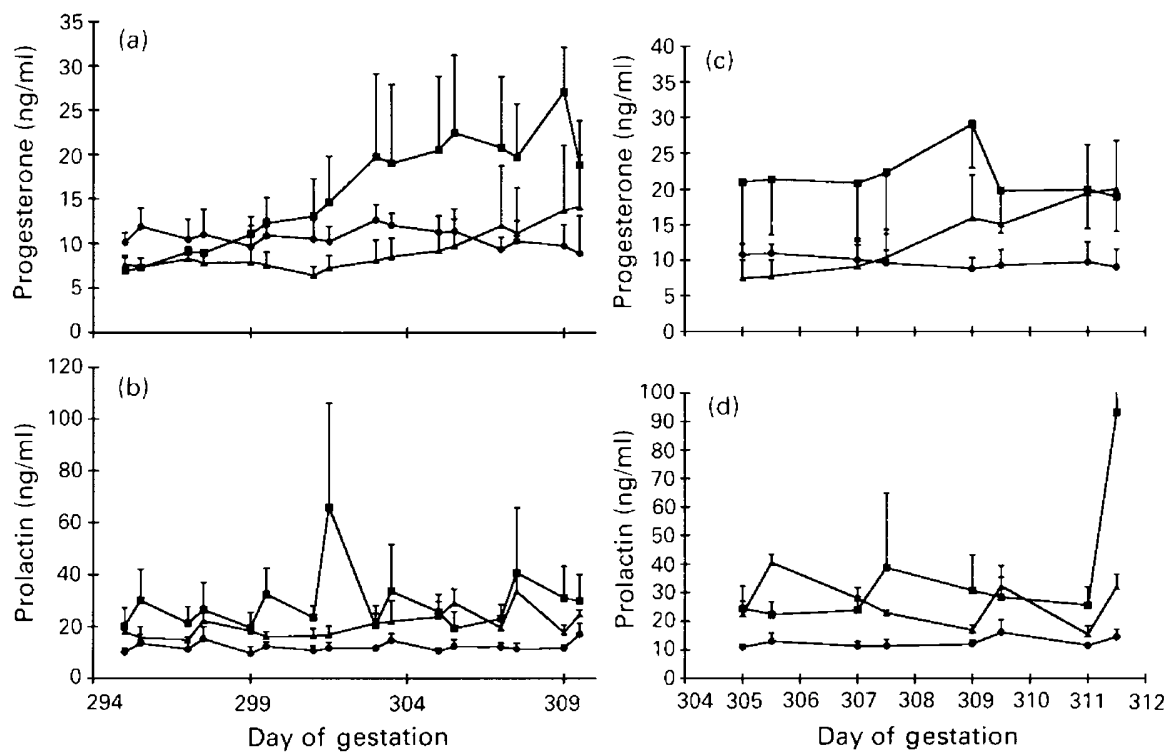

Fig. 1. Concentrations of (a) progesterone and (b) prolactin from (a and b) Day 295 to Day 309 and from (c and d) Day 305 to Day 311 of gestation in plasma of mares receiving $0.08 \mathrm{mg}$ bromocriptine/kg body wt per day from Day 295 (Group A ( )), or the same dose of bromocriptine plus $0.375 \mathrm{mg}$ perphenazine/ $\mathrm{kg}$ body wt twice a day from Day 305 (Group B ( $\Delta)$ ) or $0.9 \%$ saline (Group $\mathrm{C}(\boldsymbol{\square})$ ). Values are means \pm s.e.m.

Group A mares at Day 305 and increased to concentrations similar to those in control mares by Day 311 , in a stair-step fashion.

Analysis of blood samples collected twice a day from 10 days pre partum to foaling revealed that the mares in Group A had lower $(P<0.05)$ plasma progesterone concentrations (Fig. 2a) than Group $B$ and $C$ mares $(8.91 \pm 3.53$ vs. $17.51 \pm 3.65$ and $25.54 \pm 4.94 \mathrm{ng} / \mathrm{ml})$. The cubic subplot regressions of day $\times$ treatment for Group A vs. Groups B and $\mathrm{C}(P<0.01)$ and Group B vs. C indicated differences in the pre-partum progesterone concentration profiles due to treatment. Progesterone concentrations for Group A mares remained relatively constant until foaling. In Group B mares, progesterone remained constant until 1 day pre partum and then declined, but increased from 5 days to 1 day pre partum in control mares and then declined sharply on the day of foaling. Plasma prolactin concentrations were lower in Group A than in Group B and C mares $(13.02 \pm 6.90$ vs. $27.45 \pm 7.25$ and $100.86 \pm 9.85 \mathrm{ng} / \mathrm{ml} ; P<0.01)$ and greater $(P<0.01)$ in control than in Group B mares. Concentrations at $09: 50 \mathrm{~h}$ were lower $(P<0.01)$ than at 17:00 h $(30.32 \pm 6.58$ vs. $63.90 \pm 6.66 \mathrm{ng} / \mathrm{ml})$ suggesting a diurnal pattern. The cubic subplot regressions of day $\times$ treatment $\times$ time of day $(P<0.01)$ revealed interactions between treatment and time of day for the pre-partum prolactin concentration profiles (Fig. 2b, c). Prolactin concentrations at 17: $00 \mathrm{~h}$ were consistently greater than at $09: 50 \mathrm{~h}$ until the day of foaling for Group B and $\mathrm{C}$ mares, but the time-of-day difference was not as pronounced in Group B mares as in the control mares. Time of day did not appear to affect prolactin concentrations in Group A mares, as these values were characteristically low throughout the sampling period, regardless of the time of day the samples were collected.

\section{Clinical symptoms}

Bromocriptine produced clinical signs similar to those observed in pregnant mares grazing endophyte-infected tall fescue during late gestation. All mares in the bromocriptine-treated Group 

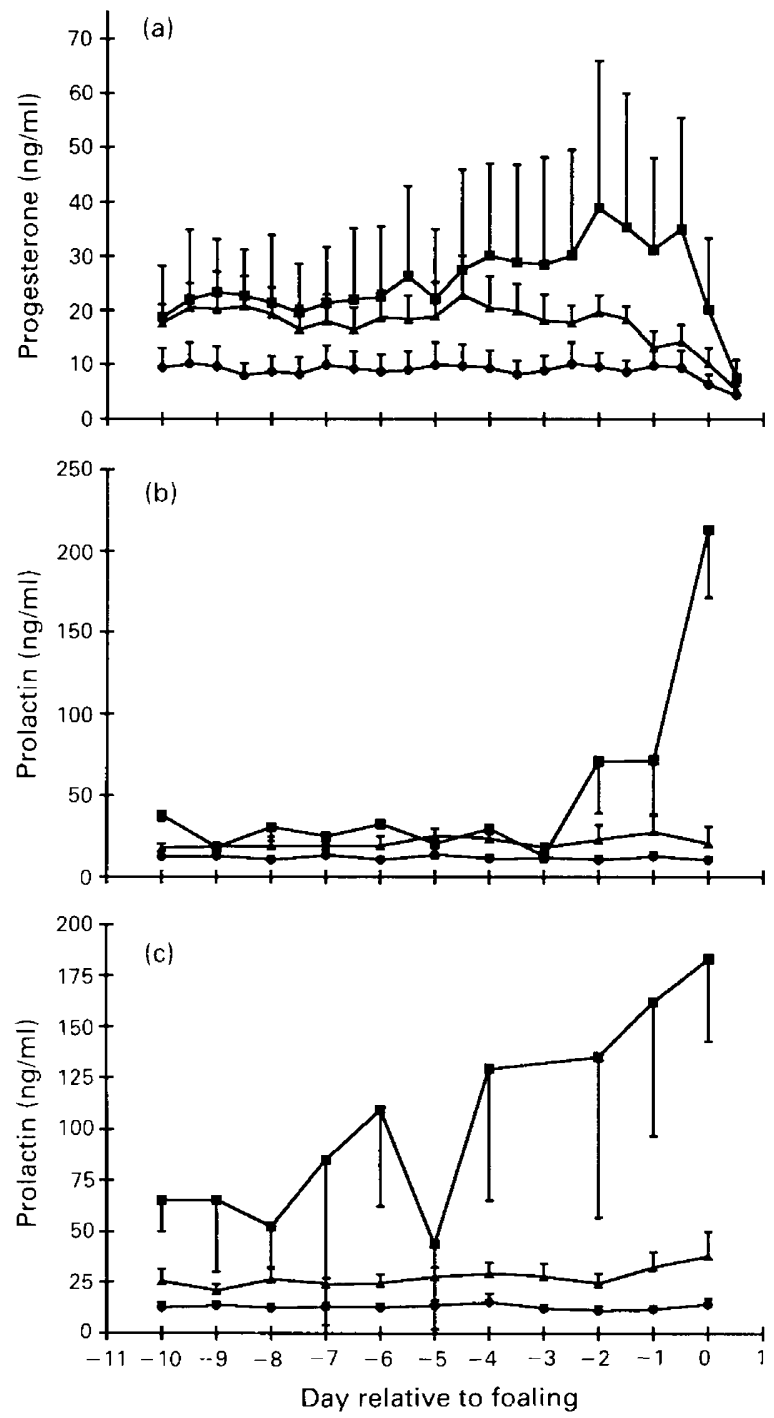

Fig. 2. Concentrations of (a) progesterone and of prolactin at (b) 09:50 h and (c) 17:00 h from 10 days pre partum to foaling in plasma of mares receiving $0.08 \mathrm{mg}$ bromocriptine $/ \mathrm{kg}$ body wt per day from Day 295 (Group A (@)), or the same dose of bromocriptine plus $0.375 \mathrm{mg}$ perphenazine $/ \mathrm{kg}$ body wt twice a day from Day 305 (Group B $(\boldsymbol{\Delta})$ ) or $0.9 \%$ saline (Group C

(D)). Values are means \pm s.e.m.

A were agalactic at foaling, while all the mares in treatment Groups B and C had a normal quantity of milk in the udder.

Mean gestation length differed between treatment groups, gestation in Group A $(342 \cdot 2 \pm 3 \cdot 2$ days) being significantly longer $(P<0.05)$ than in the controls $(322.0 \pm 3.7$ days $)$ and that in Group B being intermediate (330.8 $\pm 3 \cdot 2$ days). Mean gestation was 337 days for filly foals and 328 days for colts. Sire averages were 323, 331 and 337 days for the 3 sires represented. Because there were few foals, their sex and the sire were not considered in the statistical design.

Of the 4 mares in Group A, 2 delivered foals encased in the placenta $(50 \%)$; the other $2(50 \%)$ retained the placenta for $>3 \mathrm{~h}$ (Sager, 1949). A significant difference $(P<0.05)$ was observed 
between Group A and Groups B and C in the occurrence of dystocia and thickened placentae. Three of the mares in Group A had dystocia (75\%), while all 4 mares (100\%) had thickened, haemorrhagic placentae. One of the 3 dystocias was attributed to malpresentation of the foal. There was no incidence of dystocia, thickened or retained placentae in Groups B or C. One mare in Group B expelled the placenta at $2 \mathrm{~h}$ after foaling; the remainder of the mares in Group B and all the mares in Group C expelled the placenta within $1.5 \mathrm{~h}$ of foaling.

Post-mortem examination of the foals from mares in Group A indicated that one foal was stillborn and one died during delivery. These foals were from 2 mares that passed their placentae at delivery and account for 2 of the 3 dystocias. A third foal received no colostrum and died at 3 days of age, from septicaemia. The remaining foal was saved with the use of supplementary milk. All mares in Groups B and C delivered normal foals.

\section{Discussion}

These data provide evidence that bromocriptine reduces prolactin and progesterone concentrations in pregnant mares and induces clinical signs similar to those observed in pregnant mares grazing endophyte-infected tall fescue pastures. Although these signs have been associated with the ergot alkaloids produced by the endophyte infection, the results provide direct evidence that an ergot alkaloid will produce the signs associated with fescue toxicosis in mares.

Normal prolactin concentrations in periparturient mares have been reported previously (Worthy et al., 1986; Kosanke et al., 1987), but the frequency of sample collections was not sufficient to describe thoroughly all the events occurring. Our data suggest that prolactin concentrations in periparturient mares are higher in evening samples than in morning samples. Prolactin concentrations in morning samples in control mares were not higher than those of mares receiving bromocriptine, until immediately before parturition. Bromocriptine has been shown to reduce prolactin concentrations (McNeilly \& Land, 1979; Fitzgerald \& Cunningham, 1982; Dusza et al., 1983; Pijoan \& Williams, 1985; Johnson \& Becker, 1987) in a range of mammals. Johnson \& Becker (1987) reported that bromocriptine reduces prolactin concentrations in nonpregnant mares, only when basal concentrations of serum prolactin are at their seasonal high. Johnson \& Becker (1987) suggested that this was due to an increased affinity or number of dopamine receptor sites. The increase in normal prolactin concentrations in late gestation (Worthy et al., 1986) leads to an increased potential for a reduction by ergot alkaloids. The reduction in prolactin concentrations and the occurrence of other reproductive abnormalities reported in this paper are in agreement with previous studies involving endophyte-infected fescue pasture (Monroe et al., 1988; Taylor et $a l ., 1985$ ) and fescue seed (Kosanke et al., 1987). However, while gestation lengths were statistically different in treated and control mares, the values are not considered to be outside a normal range for mares.

Perphenazine increases prolactin concentration in humans (Musey et al., 1986) and other mammals (Vasquez et al., 1980; Sinha \& Gilligan, 1982; Vandeputte-Van Messom \& Peeters, 1982). Oral perphenazine at $0.375 \mathrm{mg} / \mathrm{kg}$ body weight twice a day increased prolactin above the low concentrations observed with bromocriptine injection, while producing no visible, adverse effects. Though the concentrations were not as high as those in the control group, the increase was sufficient to allow the initiation of lactation at foaling and to eliminate the adverse clinical signs observed with the ergot alkaloid. The secretion of prolactin is tonically inhibited by dopamine release from tuberoinfundibular neurons (Moore, 1987); the activity of these neurons is controlled by prolactin and is not altered by dopamine agonists or antagonists. The reduction in prolactin secretion following bromocriptine administration results from direct action at the pituitary (Berde \& Strumer, 1978; Mauerer, 1981) and from reduced dopamine release following the increased activation of nigrostriatal dopaminergic neurons (Moore \& Wuerthele, 1979). Perphenazine probably increases the activity of nigrostriatal neurons, directly or indirectly, causing a reduction in 
endogenous dopamine release, rather than interfering with the direct action of bromocriptine at the pituitary. Such a mechanism would explain why the mares receiving perphenazine and bromocriptine did not have prolactin concentrations similar to those in the control mares.

Progesterone concentrations were reduced in mares receiving bromocriptine, but increased to concentrations similar to those in the control mares within a few days of the onset of perphenazine administration. Bromocriptine has been reported to reduce progesterone concentrations in cycling sows (Dusza et al., 1983) and in dioestrous rats (van de Schoot \& Uilenbroek, 1983). In both of these species, the corpora lutea are the source of progesterone, whereas during late gestation in mares the source of progesterone is the placenta (Squires et al., 1974; Ganjam et al., 1975). The regulation of placental progesterone secretion in mares has not been characterized, but the reduction in progesterone concentrations following the administration of bromocriptine is consistent with the data obtained by feeding fescue seed (Konsanke et al., 1987).

The results of this experiment are in agreement with those reported by Kosanke et al. (1987), which suggest that there may be a threshold concentration for prolactin necessary to initiate lactation. This and the fact that prolactin concentrations are very variable between mares may explain why not all pregnant mares grazing tall fescue exhibit adverse signs. In addition, the seasonality of prolactin secretion in horses may be important from a management standpoint in the control of adverse clinical signs associated with fescue toxicosis. If prolactin concentrations are increased by daylength in pregnant mares, as they are in nonpregnant mares (Johnson, 1986), reproductive problems for mares foaling later in the year are less likely, assuming that the amount of ergot alkaloid consumed remains constant.

Our results indicate that ergot alkaloids affect hormone concentrations of pregnant mares. It seems possible that, by altering hormone concentrations with the use of perphenazine, clinical signs associated with fescue toxicosis in pregnant mares may be alleviated

This is Contribution Journal Series Number 11256 from the Missouri Agricultural Experiment Station. We thank Dr Harold Papkoff, University of California Medical School, San Francisco, $\mathrm{CA}$, for the anti-equine prolactin antiserum.

\section{References}

Ben-David, M., Dikstein, S. \& Sulman, F.G. (1965) Production of lactation by non-sedative phenothiazine derivatives. Proc. Soc. exp. Biol. Med. 118, $265-270$.

Ben-David, M., Danon, A. \& Sulman, F.G. (1970) Acute changes in blood and pituitary prolactin after a single injection of perphenazine. Neuroendocrinology $\mathbf{6}$, $336-342$.

Berde, B. \& Sturmer, E. (1978) Ergot alkaloids and related compounds. In Handbook of Experimental Pharmacology, pp. 1-28. Eds B. Berde \& H. O. Schild. Springer-Verlag, New York.

Dusza, L., Krzymowska, H., Kotwica, G., Ziecik, A. \& Tilton, J. (1983) Prolactin and progesterone and luteinizing hormone secretion after bromocriptine (CB-154) treatment in cyclic sows. Theriogenology 20 , $529-535$.

Fitzgerald, B.P. \& Cunningham, F.J. (1982) Effects of metoclopramide and bromocriptine on prolactin secretion in the pregnant ewe. $J$. Endocr. 93, 41-46.

Ganjam, V.K., Kenney, R.M. \& Flickinger, G. (1975) Plasma progestagens in cyclic, pregnant and post-partum mares. J. Reprod. Fertil., Suppl. 23, $441-447$.
Garrett, L. (1980) Reproductive problems of mares grazing fescue. M.S. thesis, University of Missouri Press.

Gill, J.L. \& Hafs, H.D. (1971) Analysis of repeated measurements of animals. J. Anim. Sci. 33, 331-336.

Johnson, A.L. (1986) Serum concentrations of prolactin, thyroxine and triiodothyronine relative to season and the estrous cycle in the nonpregnant mare. J. Anim. Sci. 62, 1012-1020.

Johnson, A.L. \& Becker, S.E. (1987) Effects of physiologic and pharmacologic agents on serum prolactin concentrations in the nonpregnant mare. J. Anim. Sci. 65, 1292-1297.

Kosanke, J.L., Koch, W.E., Worthy, K. \& Ellersieck, M.R. (1987) Effect of toxic tall fescue on plasma prolactin and progesterone in pregnant pony mares. Proc. 10th Equine Nutr. \& Physiol. Symp., Fort Collins, pp. 663-668.

Li, C.H. \& Chung, D. (1983) Studies on prolactin 48: isolation and properties of the hormone from horse pituitary glands. Arch. Biochem. Biophys. 220, 208-213.

Loch, W.E., Swantner, L.D. \& Anderson, R.R. (1987) The effects of four levels of endophyte-infected fescue 
seed in the diet of pregnant pony mares. $J$. Reprod. Fert., Suppl. 35, 535-538.

Loch, W., Worthy, K. \& Ireland, F. (1990) The effect of phenothiazine on plasma prolactin levels in non-pregnant mares. Equine vet. J. 22, 30-32.

Lyons, P.C., Plattner, R.D. \& Bacon, C.W. (1986) Occurrence of peptide and clavine ergot alkaloids in tall fescue grass. Science, N.Y. 232, 487-489.

Mauerer, R.A. (1981) Transcriptional regulation of the prolactin gene by ergocryptine and cyclic AMP. Nature, Lond. 294, 94-97.

McNeilly, A.S. \& Land, R.B. (1979) Effect of suppression of plasma prolactin on ovulation, plasma gonadotrophins and corpus luteum function in LH-RHtreated anoestrous ewes. J. Reprod. Fert. 56, 601 .

Moore, K.P. (1987) Interactions between prolactin and dopaminergic neurons. Biol. Reprod. 36, 47-58.

Moore, K.E. \& Wuerthele, S.M. (1979) Regulation of nigrostriatal and tuberoinfundibular-hypophyseal dopaminergic neurons. Prog. Neurobiol. 13, 325-359.

Monroe, J.L., Cross, D.L., Hudson, L.W., Hendricks, D.M., Kennedy, S.W. \& Bridges, W.C., Jr (1988) Effect of selenium and endophyte-contaminated fescue on performance and reproduction in mares. Equine vet. Sci. 8, 148-153.

Musey, V.C., Preedy, J.R.K., Musey, P.I., Blank, M.S., Brogan, D.R., Bain, R.P. \& Collins, D.C. (1986) Prolactin and blood pressure responses to perphenazine in human subjects: Comparison of the oral and intramuscular routes. Am. J. med. Sci. 291, 380-385.

Pijoan, P.J. \& Williams, J.L. (1985) The reproductive activity of autumn and spring-lambing ewes given bromocriptine during lactation. $B r$. vet. J. 141, 282-287.

Roser, J.F., Chang, Y., Papkoff, H. \& Li, C.H. (I984) Development and characterization of a homologous radioimmunoassay for equine prolactin. Proc. Soc. exp. Biol. Med. 175, 510-517.

Sager, F.C. (1949) Examination and care of the genital tract of the brood mare. $J$. Am. vet. med. Assoc. 115, 450.

Schillo, K.K., Leshin, L.S., Boling, J.A. \& Gay, N. (1988) Effects of endophyte-infected fescue on concentrations of prolactin in blood sera and the anterior pituitary and concentrations of dopamine and dopamine metabolites in brains of steers. J. Anim. Sci. 66, $713-718$.

van de Schoot, P. \& Uilenbroek, J.T.J. (1983) Reduction of 5-day cycle length of female rats by treatment with bromocriptine. J. Endocr. 97, 83 89

Sheeler, L.V., Manley, C., Bratton, G.R., Amoss, M.S., Jr \& Garner, G.B. (1985) Inhibition of prolactin release in dispersed bovine pituitary cell cultures by endophyte-infected fescue seed extract. J. Anim. Sci.. Suppl. 1. 61, 27.

Sinha, Y.N. \& Gilligan, T.A. (1982) Estrogen in high doses inhibits perphenazine-induced prolactin release. Endocrinology 110, 126-130.

Squires, E.L., Douglas, R.H., Steffenhagen, W.P. \& Ginther, O.J. (1974) Ovarian changes during the estrous cycle and pregnancy in mares. $J$. Anim. Sci. 38, 330-338.

Srikandakumar, A., Ingraham, R.H., Ellsworth, M.E., Archbald, L.F., Liao, A. \& Godke, R.A. (1986) Comparison of a solid phase, no extraction radioimmunoassay for progesterone with an extraction assay for monitoring luteal function in the mare, bitch and cow. Theriogenology 26, 776-793.

Swantner, L.D. (1986) Tall fescue effects on composition of the placenta. M.S. thesis, University of Missouri Press.

Taylor, M.C., Loch, W.E. \& Ellersieck, M.R. (1985) Toxicity in pregnant pony mares grazing Kentucky31 fescue pastures. Nutr. Rep. Int. 31, 787-795.

Vandeputte-Van Messom, G. \& Peeters, G. (1982) Effect of hypothalamic implantation of perphenazine on milk yield in goats. $J$. Endocr. 94, 267-270.

Vasquez, J.M., Nazian, S.J. \& Mahesh, V.B. (1980) Pituitary sensitivity to $\mathrm{LHRH}$ in hyperprolactinemia induced by perphenazine and renal pituitary transplants in female rats. Biol. Reprod. 22, 486-492.

Worthy, K., Escreet, R., Renton, J.P., Eckersall, P.D., Douglas, T.A. \& Flint, D.J. (1986) Plasma prolactin concentrations and cyclic activity in pony mares during parturition and early lactation. $J$. Reprod. Fert. 77, 569-574.

Received 8 August 1990 